\title{
Epidemiological considerations on HIV infection in Constanța county
}

\author{
Iulia Gabriela Șerban ${ }^{1,2^{*}}$, Sorin Rugină ${ }^{1,2}$, Consuela Marcaşš ${ }^{2}$ Ghiulendan lacub²
}

From The 9th Edition of the Scientific Days of the National Institute for Infectious Diseases Prof Dr Matei Bals Bucharest, Romania. 23-25 October 2013

\section{Background}

The epidemiological trend of evolution of HIV-AIDS is a topic of great interest to the international scientific community today.

This paper aims to formulate epidemiological considerations on the evolution of HIV infection in Constanța.

\section{Methods}

The authors performed a retrospective study on two groups of patients selected from the cohort born between 1987 and 1989, based on 2 distinct patterns of evolution: acute evolution (1987-1993) and chronic course (2009-2013).

We correlated clinical developments, therapeutic interventions and causes of death in 2 periods: 19871993 and 2009-2013.

\section{Results}

Group A (patients with natural progression of the disease), with a survival rate of 18-24 months, who received only medical care and assistance, with causes of death like opportunistic infections and high mortality type.

Group B (patients with HAART), which are derived from cohort and new detected, with a mean survival time of 10-11 years, reduced mortality, predominantly through tuberculosis or pneumocystosis, polyexperimented patients, immunologically exhausted or not adherent.

\section{Conclusion}

A retrospective epidemiological characterization of the 2 groups of patients confirmed the essential role of health care, including palliative care, especially of antiretroviral therapy in modifying the "pattern" of evolution of HIVAIDS disease.

* Correspondence: serbaniuliagabriela@gmail.com

${ }^{1}$ Ovidius University, Constanța, Romania

Full list of author information is available at the end of the article
Authors' details

'Ovidius University, Constanța, Romania. ${ }^{2}$ HIV-AIDS Constanța Regional

Center, Romania.

Published: 16 December 2013

doi:10.1186/1471-2334-13-S1-P20

Cite this article as: Șerban et al:: Epidemiological considerations on HIV infection in Constanța county. BMC Infectious Diseases 2013 13(Suppl 1): P20.
Submit your next manuscript to BioMed Central and take full advantage of:

- Convenient online submission

- Thorough peer review

- No space constraints or color figure charges

- Immediate publication on acceptance

- Inclusion in PubMed, CAS, Scopus and Google Scholar

- Research which is freely available for redistribution

Submit your manuscript at www.biomedcentral.com/submit
C Biomed Central 